PRZEGLĄD RUSYCYSTYCZNY 2020, nr 4(172)

DOI $10.31261 / \mathrm{pr} .8984$

ANNA KOŚCIOŁEK

Uniwersytet Mikołaja Kopernika w Toruniu

(D) ORCID: https://orcid.org/00oo-0001-8133-0965

\title{
KILKA UWAG NA TEMAT MŁODZIEŃCZEGO STOSUNKU ALEKSANDRA HERCENA DO CHRZEŚCIJAŃSTWA
}

\section{SOME REMARKS ON ALEXANDER HERZEN'S VIEW \\ ON CHRISTIANITY IN HIS YOUNG DAYS}

The article is an attempt to present Alexander Herzen's youthful mystical experiences on the basis of My past and thoughts and letters to his fiancée, Natalya Zakharina. Religiousness was the element of the writer's upbringing which was treated superficially in his childhood. In his youth Herzen went through a stage of mysticism. This state of mind was caused by his feelings towards his fiancée and his friendship with Alexander Witberg, an architect. The mystical period, however, did not last long. As a mature person the writer had a skeptical, critical approach to Christianity.

Keywords: Herzen, christianity, mysticism, Natalia Zakharina, Alexander Witberg

Aleksander Hercen (1812-1870) znany jest ze swego krytycznego podejścia do religii. Taka postawa towarzyszyła mu jako człowiekowi dojrzałemu. Jednak w okresie dzieciństwa i młodości wyglądało to nieco inaczej. Dlatego w tym artykule podjęta zostanie próba przedstawienia jego młodzieńczych doświadczeń religijnych na podstawie Rzeczy minionych i rozmyślań (Былое и думы) oraz listów do narzeczonej, Natalii Zacharjinej (1817-1852).

Hercen był naturalnym synem bogatego ziemianina Iwana Jakowlewa, „otrzymał wychowanie typowe dla młodych rosyjskich paniczów tej epoki, czyli miał do swojej dyspozycji całą armię służących, nauki pobierał od prywatnych guwernerów, niemieckich i francuskich, starannie dobranych przez swego neurotycznego, drażliwego, oddanego i podejrzliwego ojca. Niczego nie zaniedbano, by rozwijać uzdolnie- 
nia dziecka"1, pomyślano nawet o edukacji muzycznej, o którą dbał Iwan Iwanowicz Eck ${ }^{2}$. Jednak religijność była tym elementem wychowania, który w dzieciństwie Aleksandra Hercena został potraktowany powierzchownie ${ }^{3}$.

Chłopiec chodził „z nudów” do świątyni z matką luteranką. Nauczył się przedrzeźniać pastorów ${ }^{4}$. Dopiero gdy miał 15 lat, ojciec zatrudnił kapłana, by udzielał mu lekcji teologii „w zakresie potrzebnym do wstąpienia na uniwersytet" (Rz I, 59). Było to więc działanie o charakterze pragmatycznym. Bez wiedzy z zakresu katechizmu młody człowiek nie mógłby rozpocząć studiów. Zdaniem Jakowlewa religia była „jednym z niezbędnych atrybutów dobrze wychowanego człowieka" (Rz I, 59). Uważał on, że należy wierzyć w Pismo Święte, spełniać praktyki religijne, nie wpadając jednak w zbytnią nabożność, która przystoi tylko starszym kobietom. Sam - jak wspominał Hercen - „trochę wierzył, z przyzwyczajenia, gwoli przyzwoitości i na wszelki wypadek" (Rz I, 60), jednak praktyk religijnych nie wypełniał, usprawiedliwiając się złym stanem zdrowia. W innym miejscu Rzeczy minionych autor zauważał, że rodzic nie zachowywał postu (Rz I, 117).

Dbając o zewnętrzne formy, raz w roku ojciec kazał synowi przygotowywać się do przyjęcia sakramentów świętych. Hercen wspominał, że z obawą przystępował do komunii. Nie było to bynajmniej uczucie o charakterze religijnym, ale raczej strach, jaki wzbudza w człowieku to, co niezrozumiałe i tajemnicze. Wielkanoc, najważniejsze święto chrześcijańskie, chłopiec traktował jako okazję do zjedzenia smakołyków: pisanek, paschy.

Natalia Zacharjina, podobnie jak jej przyszły mąż, była nieślubnym dzieckiem. Jej ojciec to Aleksander Jakowlew, stryj Hercena. Od 1824 roku, gdy miała zaledwie siedem lat, aż do maja 1838, kiedy uciekła, by wziąć ślub ze swoim wybrankiem, mieszkała w domu księżnej Marii Chowańskiej, siostry Jakowlewów. „Starszemu bratu” żal było „smutnej kuzynki”, odwiedzał ją w dniu urodzin czy imie-

1 I. Berlin, Hercen i jego wspomnienia, w: tegoż, Pod prąd. Eseje z historii idei, przeł. T. Bieroń, Zysk i S-ka, Poznań 2002, s. 289.

2 W. i R. Śliwowscy, Aleksander Hercen, PIW, Warszawa 1973, s. 29.

3 O religijności w domu Hercena wspomina Ludmiła Łucewicz w interesującym szkicu Wasilij Zieńkowski o Aleksandrze Hercenie i jego filozofii, „Przegląd Filozoficzny. Nowa Seria" 2013, nr 3, s. 152-154.

4 A. Hercen, Rzeczy minione i rozmyślania, t. I, przeł. E. i W. Słobodnikowie, Książka i Wiedza, Warszawa 1951, s. 60. W dalszym tekście cytaty z tego utworu opatrzone będą skrótem Rz, numerem tomu oraz strony. 
nin, przynosił prezenty, tj. książki z dedykacjami . Jeśli jednak mógł, starał się tych wizyt unikać, gdyż odstraszał go dom, w którym się wychowywała. Poza tym dzieliła ich różnica wieku - pięć lat, która wówczas miała duże znaczenie. Hercen był już przecież studentem ${ }^{6}$.

Za przełom w ich znajomości uznawany jest 20 lipca 1834 roku. Spotkali się wówczas na Polu Chodyńskim i udali się na spacer na Cmentarz Wagańkowski, najstarszą nekropolię w Moskwie, będący jednocześnie specyficznym romantycznym parkiem, szczególnie wiosną i latem, kiedy roślinność jest w rozkwicie. Właśnie wówczas przyszły pisarz dostrzegł w kuzynce człowieka wielkiego serca7. Był to niezwykle ważny dla niego czas nie tylko z punktu widzenia relacji z Natalią. W nocy z 20 na 21 lipca 1834 roku został bowiem aresztowany w związku ze sprawą studenckiej wieczorynki, na której śpiewano „rymowane paszkwile”. Władze od dawna interesowały się środowiskami młodzieżowymi, między innymi kółkiem Hercena na Uniwersytecie Moskiewskim9. Wynikało to z atmosfery Rosji mikołajowskiej. Wszelkimi środkami starano się chronić społeczeństwo przed najmniejszymi objawami nieprawomyślności.

Hercen spędził w więzieniu osiem miesięcy, następnie został zesłany. Najpierw do Permu, później Wiatki i Włodzimierza. Okres zsyłki trwał pięć lat. W lecie 1839 roku zwolniono go spod nadzoru, w latach kolejnych zamieszkał w Petersburgu, a następnie w Nowogrodzie, dokąd został karnie przeniesiony za kolejne przestępstwo polityczne. Od roku 1843 osiedlił się na stałe w Moskwie ${ }^{10}$.

Pierwsze listy, jakie Hercen i Natalia pisali do siebie w czasie śledztwa, miały charakter przyjacielski. Znamienne jednak, że ostatnie słowa przed wyruszeniem na zesłanie przyszły emigrant skierował właśnie do „siostry” Natalii, a nie do niedawnej ukochanej, Ludmiły Passek, swojej Gaetany (Rz II, 31). Po przyjeździe do Permu, a potem Wiatki, ich korespondencja nie ustała. „Starszy brat” pisał kuzyn-

5 А. Герцен, Собрание сочинений в тридцати томах, t. XXI, Наука, Москва 1961, s. 431. W dalszym tekście cytaty z tego dzieła opatrzone będą skrótem S oraz numerem tomu i strony.

6 W. i R. Śliwowscy, Aleksander Hercen..., s. 86-88; W. Śliwowska, Aleksander Hercen, Iskry, Warszawa 2017, s. 69-71.

7 W. i R. Śliwowscy, Aleksander Hercen..., s. 88; W. Śliwowska, Aleksander Hercen..., s. 49.

8 W. i R. Śliwowscy, Aleksander Hercen..., s. 52.

9 O kółku zob.: L. Bazylow, Społeczeństwo rosyjskie $w$ pierwszej połowie XIX wieku, Zakład Narodowy im. Ossolińskich, Wrocław 1973, s. 463-465.

10 Zob. tamże, s. 465. 
ce nawet o swoich flirtach, o romansie z Praskowią Miedwiediewą ${ }^{11}$ (S XXI, 50-52).

Przez pewien czas Hercen i Natalia Zacharjina zastanawiali się, jaki charakter ma ich relacja. Wątpliwości i rozterki znalazły odzwierciedlenie w korespondencji. Gdy zrozumieli, co ich łączy, w listach dawali wyraz miłości. W korespondencji zakochanych nie było jednak elementów erotyki ${ }^{12}$. Miedwiediewa uosabiała miłość fizyczną, gdy tymczasem pisarzowi objawiła się miłość wyższa. Natalia stała się dla niego

symbolem czystości, jej listy były odtrutką na koszmar kancelarii, na towarzystwo wiackich urzędników, marzących tylko o jednym - o awansie i otrzymaniu orderu. W tej miłości szukał Hercen ratunku przed upadkiem i wiszącą nad nim groźbą: będziesz taki sam jak my wszyscy, szukać będziesz zapomnienia w wódce,

${ }^{11}$ Praskowia Miedwiediewa - żona urzędnika, kochanka Hercena. Po śmierci męża zapewne czekała na propozycję matrymonialną z jego strony. Uczucie jednak wystygło. Zesłaniec czuł się niekomfortowo z tego powodu, ale nie zamierzał wiązać się z kobietą starszą od niego, wychowującą dzieci. Później razem z żoną troszczył się o materialne zabezpieczenie Miedwiediewej i jej potomstwa (W. Śliwowska, Aleksander Hercen..., s. 73, 78).

${ }^{12}$ Przed ślubem Hercen stworzył obraz idealnej, bezcielesnej dziewicy. W literaturze tego okresu kobiecość ziemska i duchowa wcielane były w różne obrazy. Tak było i u zesłańca. Jedną była Praskowia, drugą Natalia. Gdy te dwa aspekty kobiecości miały się połączyć w jednej osobie, do tego idealnego obrazu narzeczonej w roku 1838 zaczęły dochodzić „zakamuflowane” elementy erotyczne. W liście z 21 lutego tegoż roku pisał do Natalii, że bardzo lubi w dziewczynie i kobiecie chęć do strojenia się. Oczywiście zaznaczał, że nie może ona stać się głównym wyznacznikiem życia. Wyjaśniał, że w ubiorach tkwi poezja i nie należy ich, podobnie jak zewnętrznego piękna, lekceważyć (S XXI, 295). Sądził, że troska o swój wygląd nie jest niczym złym. Zaznaczał, że damy w Wiatce chwaliły jego oczy, czoło i ręce, co sprawiało mu przyjemność, „nawet za Ciebie było mi miło" (S XXI, 330) - konstatował. Z kolei w liście pisanym po pierwszym pocałunku Hercen wyrzucał narzeczonej, że źle pojmuje poezję rozkoszy i stroju. Przekonywał Natalię, że jedzenie to konieczność, potrzeba „zwierzęca”, „niska”, natomiast rozkosz ma charakter pełen wdzięku, to dążenie do piękna. Jego zdaniem nie byłoby nic złego w tym, gdyby jej włosy ozdobione zostały brylantami. I dodawał: „Nie, aniele, wyznaję szczerze: kocham przepych, - przepych w domu i pokoi najwięcej; ale mogę bez goryczy poprzestać na kawałku chleba - to całkiem inna sprawa" (S XXI, 314). To wyznanie zdaje się dobrze określać stosunek Hercena do świata, dóbr materialnych, pokazuje ono jego pragmatyczne podejście do otaczającej rzeczywistości. Pisarz nie miał usposobienia ascety, potrafil jednak zrezygnować z tego, co w danym momencie nie było niezbędne. Prosił także narzeczoną, by zwróciła uwagę na strój, w którym zostanie sportretowana. Miała to być prosta, powiewna, ledwie materialna kreacja (S XXI, 330). W takich właśnie uwagach dotyczących ubioru i podejścia do życia uzewnętrzniała się owa „ukryta” erotyka. 


\section{KILKA UWAG...}

przelotnych miłostkach, piąc się będziesz po szczeblach kariery i osiągnąwszy to wszystko, niczego nie osiągniesz z tego, o czym w swej naiwności marzyłeś. I ratunek ten znajdował ${ }^{13}$.

Listy do Natalii Zacharjinej zawierają również wyznania o charakterze religijnym. W jednym z nich Hercen wspominał, że do roku 1834 obce były mu jakiekolwiek idee religijne. Później jednak zaczął postrzegać świat jako niepełny, niewystarczający. Takie myśli i wrażenia nasiliły się podczas pobytu w więzieniu. Odczuwał wówczas potrzebę lektury Ewangelii. Należy przypomnieć, że już w dzieciństwie przyszły pisarz często czytał tę księgę w języku niemieckim i cerkiewnosłowiańskim, dlatego znał ją dobrze:

Ewangelię czytałem często i z zamiłowaniem: w języku cerkiewnosłowiańskim i w przekładzie Lutra. Czytałem bez wszelkich wskazówek, nie wszystko rozumiejąc, lecz czując szczery i głęboki szacunek do tego, co czytałem [...] nie pamiętam, bym kiedykolwiek ozięble brał do ręki Ewangelię; uczucie to towarzyszyło mi przez całe życie; w każdym wieku, w różnych okolicznościach wracałem do czytania Ewangelii i za każdym razem treść jej przepełniała mnie spokojem i radością (Rz I, 60-61).

Zatrudniony przez ojca kapłan był zaskoczony, że chłopak potrafil cytować obszerne fragmenty z Pisma Świętego. W czasie pobytu w więzieniu Hercen czytał Ewangelię ze łzami w oczach (S XXI, 158). Uświadomił sobie, że świat to „marność nad marnościami” i zaczął szukać ojczyzny duszy, miejsca, gdzie mógłby znaleźć spokój, którego mu w życiu brakowało. Postawa wewnętrznej równowagi cechowała jego zdaniem apostołów i świętych. Dlatego z zainteresowaniem czytał utwory hagiograficzne (S XXI, 28), podziwiał przykłady poświęcenia męczenników. Brakowało mu jednak, jak sam podkreślał, czystości duszy. Doświadczył wszakże cudu. Narzeczona niejako stworzyła go na nowo, ona sprawiła, że zmieniło się całkowicie jego podejście do życia. Zaczął inaczej patrzeć na wszystko: przyrodę, człowieka i Boga. Dzięki Natalii, jak sam wyznawał, stał się chrześcijaninem (S XXI, 159). Uczestniczył w obrzędach cerkiewnych, starał się odkrywać ich głęboki sens. Nie zawsze potrafił się jednak modlić. Ze względu na wychowanie i wcześniejsze doświadczenia trudno mu też było brać prawdziwie pełny udział $\mathrm{w}$ liturgii i sakramentach. Jego zdaniem wynikało to z przywiązania do tego, co materialne, z postrzegania rzeczywistości w kategoriach rozumowych, a nie za pomocą serca

${ }^{13}$ W. i R. Śliwowscy, Aleksander Hercen..., s. 95. 
(S XXI, 161)14. W korespondencji prosił więc narzeczoną o modlitwę w swojej intencji.

Hercen stwierdzał, że bez Natalii był „moralnym potworem, człowiekiem bez serca" (S XXI, 106). Wielokrotnie podkreślał, że jej miłość przeobraziła go wewnętrznie, zbawiła. To ona - niby Tamara z poematu Michała Lermontowa Demon (Демон) - miała pojednać go ze Stwórcą (S XXI, 99). Dzięki niej zaczynał rozumieć, czym jest rozmowa z Bogiem. Narzeczeni mieli nawet swoją godzinę dla wspólnej modlitwy, o siódmej rano. Hercen wyznawał, że nigdy nie przespał tej pory (S XXI, 358).

Wypowiadał się również na temat roli obrazów w życiu prawosławnych. Pisał, że ikona jest święta dla tego, kto w nią wierzy. Uznawał ją za narzędzie pomagające człowiekowi wznosić się ku świętości (S XXI, 149), czyli była dla niego „oknem ku wieczności”.

Egoizm określił mianem trądu, dżumy ludzkich dusz. To mrok, spadek po Lucyferze (S XXI, 99), narzędzie, którym posługuje się upadły anioł (S XXI, 160). Przeciwstawiał mu Miłość, jako światło, będące spuścizną otrzymaną przez człowieka od Boga. Później wła-

${ }^{14}$ To bardzo ważne stwierdzenie, zważywszy na rolę serca $\mathrm{w}$ prawosławiu. W Biblii serce jest ośrodkiem osobowości człowieka, jego woli. „Według Żydów, jest to centrum myśli, gdyż obejmuje ono wszystkie zdolności ducha ludzkiego" (P. Evdokimov, Prawosławie, przeł. J. Klinger, Instytut Wydawniczy Pax, Warszawa 2003, s. 71). W pojęciu biblijnym, to właśnie w sercu powstają myśli i podejmowane są decyzje. W sercu człowiek szuka Boga, służy $\mathrm{Mu}$, wielbi i kocha Go (Filokalia: teksty o modlitwie serca, przekł. i oprac. ks. J. Naumowicz, Wydawnictwo Benedyktynów, Tyniec 1998, s. 31). Prawosławie przejęło taką koncepcję. Serce „jest najważniejszym organem istoty ludzkiej, punktem styczności umysłu i materii, ośrodkiem zarazem fizycznej budowy człowieka i jego struktury psychicznej oraz duchowej" (K. Ware, Moc Imienia. Modlitwa Jezusowa $w$ duchowości prawosławnej, w: E. Behr-Sigel, Miejsce serca. Wprowadzenie $w$ duchowość prawostawną, przeł. A. Kocot, Wydawnictwo Uniwersytetu Jagiellońskiego, Kraków 2008, s. 191), „określa nie same emocje i uczucia, lecz całość osoby ludzkiej” (K. Ware, Moc Imienia..., s. 188), „oznacza najgłębsze wnętrze człowieka. Jest siedzibą umysłu, życia, pamięci” (Fïlokalia..., s. 31). Serce zatem to nie tylko materialny organ ciała, „serce fizyczne to zewnętrzny symbol nieograniczonych możliwości duchowych człowieka, stworzonego na obraz i podobieństwo Boga" (K. Ware, Moc Imienia..., s. 188). Jest ono centrum istoty ludzkiej i miejscem jej spotkania ze Stwórcą, ale jednocześnie poznania samego siebie jako świątyni Bożej (tamże, s. 189). Serce to symbol niezmierzonej głębi człowieka, jego prawdziwego „Ja”, ośrodek, promieniujący i przenikający całe jestestwo(P.Evdokimov, Prawosławie..., s. 71), zktórego „wytryskują myśli, uczucia i chęci” (E. Behr-Sigel, Miejsce serca..., s. 121). Wyraża ono „niewypowiedzianą głębię człowieka ukrytego [...]” (P. Evdokimov, Prawosławie..., s. 73). 
ściwie rozumiany egoizm stał się dla Hercena podstawą ludzkiej osobowości, godności jednostki ${ }^{15}$.

W listach arystokrata idealizował ukochaną, nazywał ją „aniołem”, swoim „aniołem stróżem”, „gołębicą”, „gwiazdą poranną”, „promieniem światła”, swoim „Chrystusem”, „Madonną”, „świętą Dziewicą”, „boską Dziewicą”" idealna dziewica-anioł jawiła mu się jako wybawicielka, zesłana, by odkupił swój grzech, czyli romans z Praskowią Miedwiediewą. To Natalia niczym Beatrycze prowadziła go do raju (S XXI, 78), obudziła z uśpienia (S XXI, 57), podarowała (S XXI, 69) czy też zwróciła mu niebo (S XXI, 153). Ona - jak pisał - odrywała go od dusznej ziemi i przenosiła do raju (S XXI, 166). Jej imię porównał do znaku krzyża, za pomocą którego odstraszał, odpychał wszystko, co nieczyste (S XXI, 253). W jednym z listów konstatował, że wstążka, bransoleta, medalion, pierścionek to antymins ${ }^{17}$ jego duszy (S XXI, 333), a później w Dzienniku (Дневник) wyznawał, że miłość do kuzynki to jego „święte świętych” (S II, 261).

Siebie nazywał upadłym aniołem, Natalię zaś drogą, dzięki której będzie mógł się podnieść z upadku. Odwołując się do ewangelicznej przypowieści (por. Łk 15, 1-7), stwierdzal, że zadaniem narzeczonej jest znalezienie jednej zagubionej owcy (S XXI, 118).

Według Hercena ich związek był idealny, stali się jedną istotą, której ciałem był on, a duszą Natalia (S XXI, 231). W tej egzaltacji marzył, by umarli w chwili, gdy kapłan zaślubi ich obrączkami (S XXI, 249) ${ }^{18}$. Uroczystość zaślubin była co się zowie romantyczna. Natalia

${ }^{15}$ Zob. A. Kościołek, „Człowiek powinien być szlachetny”. Kilka uwag o pragmatycznej antropologii Aleksandra Hercena, „Slavia Orientalis” 2009, nr 3, s. 282284.

${ }^{16}$ Później Hercen krytycznie oceniał styl swoich listów do narzeczonej (zob.: S VIII, $345-346)$.

${ }^{17}$ Antymins to płócienny lub lniany kwadratowy obrus z przedstawieniem Chrystusa złożonego w grobie, postaci czterech ewangelistów oraz z zaszytą cząstką relikwii na pamiątkę celebrowania Eucharystii na grobach męczenników przez pierwszych chrześcijan. Bez antyminsu nie można sprawować Boskiej Liturgii.

${ }^{18}$ Warto przypomnieć, że w prawosławiu obrzęd ślubu składa się z dwóch części: zaręczyn i koronacji. Zaręczyny początkowo były ceremonią świecką, formą kontraktu, jaki zawierali ludzie. W tej części kapłan pyta przyszłych małżonków, czy chcą z dobrej woli i bez przymusu zawrzeć związek małżeński i czy nie przyrzekli małżeństwa innej osobie. Narzeczeni wymieniają się obrączkami, które są symbolem wierności, jaką sobie ślubują. Po obrzędzie zaręczyn narzeczeni wraz z kapłanem przechodzą do środka świątyni i stają przed anałojem, na którym znajdują się: Ewangelia, krzyż, korony ślubne i wino (E. Przybył, Prawosławie, Znak, Kraków 2006, s. 200-201). W świetle powyższych informacji obrączka jako znak wierności, nierozerwalności świadczy o uczuciach Hercena, ale jednocześnie 
Zacharjina potajemnie uciekła $\mathrm{z}$ domu opiekunki, narzeczeni pobrali się w cerkwi we Włodzimierzu nad Klaźmą 9 maja 1838 roku.

Nastroje mistyczne spowodowane były nie tylko uczuciem do kuzynki, ale i przyjaźnią z architektem Aleksandrem Witbergiem (1787-1855), oskarżonym o malwersacje w czasie budowy według jego projektu świątyni Chrystusa Zbawiciela w Moskwie na Wzgórzach Worobiowych. W Rzeczach minionych wspomnienia o tym człowieku połączone zostały z przedstawieniem przemyśleń autora o architekturze $^{19}$, jego zdaniem, najbardziej mistycznej dziedzinie sztuki (zob. Rz I, 334).

Hercen dał krótką charakterystykę architektury sakralnej, poczynając od starożytnego Egiptu. Świątynię Salomona określił mianem budowli-Biblii (Rz I, 334). Zwracał uwagę, że samo wznoszenie przybytku było pełne obrzędów mistycznych, średniowieczni budowniczowie uważali się za kapłanów i zrzeszali w tajne związki, które przerodziły się w masonerię. W jego opinii architektura utraciła ów mistyczny charakter w okresie renesansu. Bazylikę świętego Piotra pisarz uznał za początek „uwolnienia się rodzaju ludzkiego od habitu” (Rz I, 334). Jego zdaniem „w jej olbrzymich kształtach chrześcijaństwo rwie się do życia, kościół staje się pogański i Buonarotti maluje na ścianie Kaplicy Sykstyńskiej Jezusa Chrystusa, jako barczystego atletę, Herkulesa w pełni rozkwitu sił” (Rz I, 335). Po wzniesieniu bazyliki świętego Piotra architektura sakralna według Hercena upadła i polegała jedynie na powtarzaniu „w różnych rozmiarach to starogreckich perypterów ${ }^{20}$, to bazyliki św. Piotra” (Rz I, 335). Jego zda-

wskazuje na pewną nieznajomość porządku, bowiem sakrament następuje po obrzędzie zaręczyn. Pisarz nie wspominał o koronacji.

${ }^{19} \mathrm{~W} 1836$ roku w Wiatce Hercen zapoznał się z dziełem jednego z najsłynniejszych nie tylko w Europie, ale i na świecie geodetów, architektów oraz inżynierów budownictwa wodnego Carla Friedricha von Wiebekinga, na temat architektury cywilnej zarówno teoretycznej, jak i praktycznej (Theoretisch-practische bürgerliche Baukunde, durch Geschichte und Beschreibung der merkwürdigsten antiken Baudenkmahle und ihrer genauen Abbildungen bereichert) (Летопись жизни и творчества А. И. Герцена. 1812-1870, t. I, сост. Г. Г. Елизаветина [и др.], ред. И. Г. Птушкина, Наука, Москва 1974, s. 109). O tej lekturze wspominał w liście do przyszłej żony z 12 grudnia 1836 roku (S XXI, 127-128). O zainteresowaniu architekturą świadczy również wypowiedź epistolarna z 10 stycznia następnego roku (S XXI, 135). 13 stycznia tegoż roku donosił Natalii, że ukończył artykuł o architekturze (S XXI, 288), niestety, do nas doszły jedynie fragmenty tego tekstu, który powstał pod wpływem rozmów z Witbergem.

${ }^{20}$ Perypter (gr. perípteros) - typ świątyni greckiej opartej na planie prostokąta, w której część stanowiąca pomieszczenie dla bóstwa otoczona jest ze wszystkich 
niem „nowe kościoły tchnęły sztucznością, obłudą, anachronizmem” (Rz I, 335). Nakreślenie tego tła historii architektury sakralnej było potrzebne Hercenowi, by podkreślić wyjątkowość projektu Witberga, który uznał za „genialny, straszny i szalony” (Rz I, 337).

Przypomnijmy: Aleksander I po pokonaniu Napoleona ślubował, że wybuduje w stolicy ogromną katedrę ku czci Zbawiciela. W tym celu ogłoszono międzynarodowy konkurs na projekt świątyni. Cara zainteresował „kolosalny, pełen religijnej poezji” (Rz I, 333) pomysł nieznanego twórcy. Jego koncept zakładał troistość i niepodzielność, „jak główny dogmat chrześcijaństwa” (Rz I, 336). Dolna świątynia, wykuta w górze, powinna mieć kształt równoległoboku, grobu, ciała. W tej krypcie mieli spoczywać bohaterowie, którzy polegli w 1812 roku. Srodkową cerkiew Witberg chciał zbudować na planie greckiego krzyża, świątyni „otwartych ramion, życia, cierpień i pracy” (Rz I, 337), a prowadzącą do niej kolumnadę ozdobić posągami postaci ze Starego Testamentu: „U wejścia stali prorocy. Stali oni zewnątrz świątyni, wskazując drogę, po której nie dane im było pójść. Wnętrze tej świątyni zawierało całą historię Ewangelii i historię dziejów apostolskich" (Rz I, 337). Ukoronowaniem zamysłu architekta miała się stać budowla w kształcie rotundy, świątynia „ducha, niezmąconego spokoju i wieczności” (Rz I, 337).

Car zapoznał się z całą koncepcją, zaprosił artystę na rozmowę, a następnie zatwierdził jego projekt. Aleksander Witberg został mianowany architektem świątyni i dyrektorem komisji budowlanej. Zdaniem Hercena przyjęcie tej funkcji przez młodego niedoświadczonego człowieka było błędem. Jego współpracownicy, jak pisał autor Rzeczy minionych, „czuli się urażeni współpracą z młokosem, który śmiało wyrażał swoje zdanie i oponował, jeśli się z nimi nie zgadzał" (Rz I, 339). Oskarżony o malwersacje architekt przez wiele lat usiłował udowodnić swoją niewinność. Został skazany na zesłanie. Hercen poznał go w Wiatce. Podziwiał hart ducha tego człowieka. Pod jego wpływem sięgnął do dzieł mistyków: Karola Eckartshausena, Saint-Martina, Paracelsusa, Emanuela Swedenborga ${ }^{21}$. Nazywał Witberga człowiekiem genialnym, który pragnął górę przekształcić w świątynię, chciał kamieniowi dać siłę tekstu ewangelicznego, ale nie został

stron rzędem kolumn (hasło „perypter” w: Stownik wyrazów obcych, red. J. Tokarski, PWN, Warszawa 1980, s. 567).

${ }^{21}$ W. i R. Śliwowscy, Aleksander Hercen..., s. 72. W jednym z listów prosił o przysłanie Arcana Coelestia Swedenborga, nie wymieniał tytułu dzieła, prosił о „Сведенборговы духовидения” (S XXI, 112). 
zrozumiany (S XXI, 135). Dziękując architektowi za przyjaźń, Hercen poetycko stwierdzał, że ten był dla niego Wergiliuszem prowadzącym zabłąkanego Dantego (S XXI, 250-251).

Odbicie nastrojów mistycznych odnaleźć można we wczesnych utworach pisarza, a mianowicie w Legendziе (Легенда) i tekście Myśl a objawienie (Мысль и откровение). Legenda to wolny przekład opowieści hagiograficznej o św. Teodorze. Pierwotna wersja utworu powstała w roku 1835. Zadedykował go swojej przyszłej żonie. Siedem epigrafów do rozdziałów zaczerpną z Pisma Świętego, zarówno ze Starego, jak i Nowego Testamentu, dwa z innej literatury religijnej (św. Augustyn, Żywot świętej Katarzyny). Z kolei Myśl a objawienie to tytuł artykułu, który nie zachował się do naszych czasów. Pochodził z cyklu pt. Spotkania (Встречu). Jego pomysł powstał w czasie zesłania pisarza do Wiatki w roku 1836. Ta część znana jest także jako Trzecie spotkanie (Третья встреча) albo Szwed (Швед) ${ }^{22}$. Dokładna analiza tych utworów wymagałaby odrębnego studium.

Podsumowując, należy powiedzieć, że w dzieciństwie obojętność wobec religii wynikała ze sposobu wychowania, kształtowania osobowości Hercena. Postawa ojca, który wierzył „na wszelki wypadek” nie mogła być wzorem do naśladowania. W młodości przyszły pisarz był człowiekiem poszukującym, przeszedł przez etap mistycyzmu. Takie nastroje związane były z miłością do Natalii Zacharjinej oraz przyjaźnią z Aleksandrem Witbergiem. Jednak okres mistyczny nie trwał długo, po lekturach filozoficznych, refleksji nad różnymi aspektami ludzkiego życia coraz ostrzejsza stawała się krytyka religijnego spojrzenia na świat:

Pod wpływem Witberga zacząłem się wahać. Lecz realna moja natura wzięła jednak górę. Nie było mi sądzone wznosić się do trzeciego nieba, urodziłem się bowiem jako człowiek całkowicie ziemski. Pod dotknięciem moich rąk nie wirują stoliki, a od mego spojrzenia nie chwieją się pierścionki. Dzienne światło myśli bliższe mi jest niż księżycowa poświata fantazji (Rz I, 345).

Hercen odrzucił przekonanie o nieśmiertelności ludzkiej duszy. Sądzil, że ten, kto nie wierzy w życie pozagrobowe, może lepiej ocenić doczesne. Wie bowiem, że nic lepszego go już nie spotka ${ }^{23}$. Zawsze bliskie były mu ideały indywidualizmu, wolności, godności jednostki, otwierał się na wszystko, co ludzkie, ale bez perspektywy Transcen-

${ }^{22}$ И. Нович, Молодой Герцен. Искания, идеи, образы, личность, Советский писатель, Москва 1980, s. 188.

${ }^{23}$ A. Hercen, Eseje filozoficzne. Rosja i stary świat, przeł. W. Bieńkowska, tł. przejrzał oraz wstępem i przypisami opatrzył A. Walicki, PWN, Warszawa 1966, s. 580. 
dencji. Dojrzałego Hercena cechował sceptycyzm oraz krytyczne podejście do religii. Co prawda wysoko cenił moralność chrześcijańską, ale był przekonany, że w praktyce uległa ona zniekształceniu.

\section{REFERENCES}

Bazylow, Ludwik. Społeczeństwo rosyjskie $w$ pierwszej połowie XIX wieku. Wrocław: Zakład Narodowy im. Ossolińskich, 1973.

Behr-Sigel, Elisabeth. Miejsce serca. Wprowadzenie $w$ duchowość prawostawną. Transl. Kocot, Anna. Kraków: Wydawnictwo Uniwersytetu Jagiellońskiego, 2008.

Berlin, Isaiah. "Hercen i jego wspomnienia.” Berlin, Isaiah. Pod prą. Eseje z historii idei. Transl. Bieroń, Tomasz. Poznań: Zysk i S-ka, 2002. 286-314.

Evdokimov, Paul. Prawosławie. Transl. Klinger, Jerzy. Warszawa: Instytut Wydawniczy Pax, 2003.

Filokalia. Teksty o modlitwie serca. Transl. and ed. ks. Naumowicz, Józef. Tyniec: Wydawnictwo Benedyktynów, 1998.

Gertsen, Aleksandr. Sobraniye sochineniy $v$ tridtsati tomakh. Vol. I-XXX. Moskva: Nauka, 1954-1965 [Герцен, Александр. Собрание сочинений в тридцати томах. T. I-XXX. Москва: Наука, 1954-1965].

Hercen, Aleksander. Eseje filozoficzne. Rosja i stary świat. Transl. Bieńkowska, Wiera. Tł. przejrzał oraz wstępem i przypisami opatrzył Walicki, Andrzej. WarSzawa: PWN, 1966.

Hercen, Aleksander. Rzeczy minione i rozmyślania. Vol. I. Transl. Słobodnikowie, Eleonora \& Włodzimierz. Warszawa: Książka i Wiedza, 1951.

Kościołek, Anna. “'Człowiek powinien być szlachetny'. Kilka uwag o pragmatycznej antropologii Aleksandra Hercena.” Slavia Orientalis 2009, № 3. 279-292.

Letopis' zhizni i tvorchestva A. I. Gertsena. 1812-1870. Vol. I. Comp. Yelizavetina, Galina Georgiyevna, et al. Ed. Ptushkina, Inna Grigor'yevna. Moskva: Nauka, 1974 [Летопись жизни и творчества А. И. Герцена. 1812-1870. Т. I. Сост. Елизаветина, Галина Георгиевна, и др. Ред. Птушкина, Инна Григорьевна. Москва: Наука, 1974].

Łucewicz, Ludmiła. "Wasilij Zieńkowski o Aleksandrze Hercenie i jego filozofii." Przegląd Filozoficzny. Nowa Seria 2013, no. 3. 149-164.

Novich, Ioann. Molodoy Gertsen. Iskaniya, idei, obrazy, lichnost'. Moskva: Sovet·skiy pisatel', 1980 [Нович, Иоанн. Молодой Герцен. Искания, идеи, образы, личность. Москва: Советский писатель, 1980].

Przybył, Elżbieta. Prawostawie. Kraków: Znak, 2006.

Stownik wyrazów obcych. Ed. Tokarski, Jan. Warszawa: PWN, 1980.

Śliwowscy, Wiktoria \& René. Aleksander Hercen. Warszawa: PIW, 1973.

Śliwowska, Wiktoria. Aleksander Hercen. Warszawa: Iskry, 2017.

Ware, Kallistos. "Moc Imienia. Modlitwa Jezusowa w duchowości prawosławnej." Behr-Sigel, Elisabeth. Miejsce serca. Wprowadzenie $w$ duchowość prawostawną. Transl. Kocot, Anna. Kraków: Wydawnictwo Uniwersytetu Jagiellońskiego, 2008. 